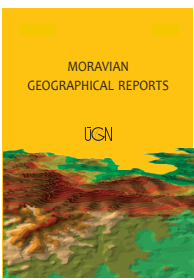

MORAVIAN GEOGRAPHICAL REPORTS

\title{
Biogeomorphological effects of leaf accumulations in stepped-bed channels: Exploratory study, Moravskoslezské Beskydy Mountains, Czech Republic
}

\author{
Zdeněk PŘIBYLA a , Tomáš GALIA a *, Jan HRADECKÝ a
}

\begin{abstract}
The stepped-bed system, with a step-like longitudinal profile, is typical morphology in steep headwater streams. These systems are created by a series of coarse sediments or instream wood (steps with supercritical flows) interspaced with finer material (forming pools with subcritical flows). In the case of well-developed steps and pools, the resulting channel-reach morphology is referred to as "step-pool" morphology. In this study, we identify a previously undescribed type of step-pool formation, the "foliaged step-pool", in the highgradient Stoligy Stream of the Moravskoslezské Beskydy Mountains. The defining feature of this formation is the significant presence of leaves in the step structure. The geometry of the steps and pools was measured and the parameters that characterise the distribution, amount and function of leaves acting in these areas were defined. Statistical results showed differences between non-foliaged and foliaged step-pool formations, in which the latter showed a significant increase in storage level, influencing the channel's hydrodynamics. Particle-size analyses demonstrated that foliaged step-pool formations had finer sediment in the pools, which indicates that there are differences in sediment transport processes between foliaged and non-foliaged formations. These results offer new insights into stepped-bed and step-pool morphology, providing directions for further research on small streams in deciduous forested regions.
\end{abstract}

Key words: mountain streams, foliaged step-pool, leaf accumulation, instream wood, Moravskoslezské Beskydy Mts., Czech Republic

Article history: Received 28 April 2015; Accepted 5 February 2016; Published 30 September 2016

\section{Introduction}

Fluvial systems are influenced to varying degrees by living organisms and their dead remains. This is exemplified by the impact of trees on river channels. Living trees armour channel banks with their roots, decreasing the rate of lateral erosion and the possibility of activating bank failures or landslides. Similarly, vegetation on channel benches reinforces sediments, making these forms more stable during flood events. The interception ability of trees significantly decreases the total amount of water delivery into fluvial systems. Instream wood fragments also directly affect river systems. Large wood pieces (LW) include a variety of coarse woody material (such as logs, branches, stumps and roots) that are $\geq 0.1 \mathrm{~m}$ in diameter and usually at least $0.5-1 \mathrm{~m}$ in length; these generally originate when trees and shrubs fall apart and the pieces are delivered into channels (Máčka and Krejčí, 2010). LW-created structures (e.g. steps and pools) retain sediment and increase the bed roughness, bankfull depth and mean particle size; they also reduce sediment transport relative to reaches that lack LW (Bilby and Ward, 1989; Curran and Wohl, 2003; Faustini and Jones, 2003; Gomi et al., 2003; Wilcox and Wohl, 2006; Burrows et al., 2012; Scott et al., 2014). LW accumulations decrease the probability of bed particle movement during high flows and reduce the mean travel distance of entrained particles, thus reducing sediment transport efficiency (Faustini and Jones, 2003). Small wood pieces (SW) are defined as woody particles (such as logs, branches and roots) that are $\leq 0.1 \mathrm{~m}$ in diameter. Wallace et al. (2000, 2001) and Burrows et al. (2012) documented that SW can have an important effect on channel processes in narrow headwaters with lower discharges.

Leaf litter can also affect the channels of small mountain streams independently of SW or LW. Although the field of fluvial geomorphology has expanded in the past two decades to include greater knowledge of channel-reach

a Department of Physical Geography and Geoecology, University of Ostrava, Ostrava, Czech Republic (*corresponding author: T. Galia, e-mail: tomas.galia@osu.cz) 
morphology and processes related to high gradient streams, the influence of leaf litter is poorly characterised. Interdisciplinary research on the effects of leaf litter has usually described results from a hydrobiological point of view or it has focused on transport dynamics; however, the distribution of leaf patches is one of the main aims of leaf research (Richardson, 1992; Pretty and Dobson, 2004; Hoover et al., 2006; Kochi et al., 2009). Terrestrially-derived leaf litter is a critical resource in many small streams, providing food and habitat for decomposers, detritivores and macroinvertebrates (Richardson, 1992). Hoover et al. (2006) described the principles of movement and deposition of leaves in pool-riffle channel-reach systems. They concluded that flow velocity and the presence of coarse sediments in the channel were the main factors influencing mean transport velocity and the distance over which leaves were deposited. Leaf transport distances were 2.6 times greater in riffle units than in pool channel units; the leaves also had a higher transport velocity. Kochi et al. (2009) investigated the differences between green leaves (from the current year) and senescent leaves (from previous years). Senescent leaves were retained in greater numbers on large wood pieces and in backwaters than were green leaves, which were usually trapped by cobbles. Both studies noted that floating leaves were stored more frequently when the grain-size parameters of the channel bed increased.

All species of deciduous trees are potential sources of leaf litter; in our study area, the predominant trees were beech and maple (Fagus sylvatica and Acer pseudoplatanus). Larger leaves, however, have higher potential to be deposited on obstacles in the stream channel (Kochi et al., 2009). Once leaves reach the channel, they become an integral part of the fluvial system and they are stored or transported downstream by flowing water (Hoover et al., 2006). The amount of organic matter stored in a streambed depends on climate, stream order and retention structures in the streambed (Hoover et al., 2006). The discharge and stream velocity necessary for effective transport of leaves is less than for bedload transport of solid particles. Thus, leaves are transported during much lower flow events, meaning that the morphology of foliaged forms has high temporal dynamics. During transport, organic matter may be retained by structures in the streambed such as woody debris and cobbles, or by backwaters behind obstacles (Kochi et al., 2009). Deposition of leaves is usually realised in contact zones with obstacles, and typically occurs on larger boulders or LW (Hoover et al., 2006). Transported leaves gradually accumulate and cover boulders or SW/

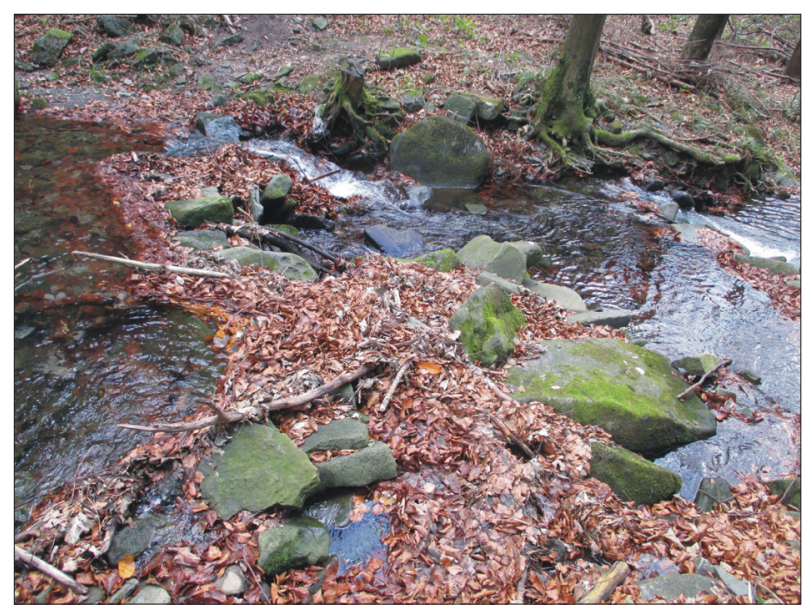

Fig. 1: Leaf accumulations (litter patches) on large boulders. Photo: Z. Přibyla
LW steps, creating "foliaged forms" (Fig. 1). An armoured isolation layer of leaves develops due to mutual adhesion between wet leaves. This layer is practically waterproof and concentrates the direction of water flow into single points on a step (Přibyla and Hradecký, 2009). Leaves accumulated over the long-term gradually subside; the total height of steps decreases and leaves lose their isolation characteristics as anaerobic biologic decomposition occurs (Kochi et al., 2009). A higher amount of leaves is observed in the steps of steppool systems, whereas in pool-riffle reaches, leaves tend to be stored in pools (Hoover et al., 2006).

The goal of this study is to evaluate the influence of leaves on the geometric parameters, grain-size characteristics and stability of bedforms in steep headwater channels with cascade and step-pool channel-reach morphologies. Cascades and step-pools generally occur over a wide range of steep channel gradients, which usually exceed $0.04 \mathrm{~m} / \mathrm{m}$ in confined valleys; they are characterised by longitudinally and laterally disorganised bed material that typically consists of gravels, cobbles and boulders (Montogomery and Buffington, 1997). Alternation between coarser sediments in the steps and finer sediments in the pools gives rise to a staircase-like longitudinal profile (Chin, 2002). The steps usually consist of relatively large, immobile boulders with a random spatial distribution in the channel. Smaller cobbles accumulate around the large boulders creating stable steps. Pools form downstream of the steps due to the scouring action of water off the crest of the steps. The pools contain relatively finer gravel and sand, and this material is transported more often (several times per year). Pool depth is controlled by the step height and discharge regime (Comiti et al., 2005). Montgomery and Buffington (1997) distinguished cascade and step-pool morphology by the length of the pools, defining cascade reach as having pools with a shorter length than bankfull channel width. Comiti and Mao (2012) characterised cascades and step-pools as part of a stepped-bed morphology within the channel-reach system. For poorly-developed significant steps and pools, the channel-reach morphology is referred to as "plane bed" or "rapid", sensu Montgomery and Buffington (1997) and Zimmermann and Church (2001).

Three of the most important and commonly-studied geomorphic variables of step-pool channels are the step height, wavelength and channel slope (Zimmermann and Church, 2001). Another important parameter is the step steepness $(\mathrm{H} / \mathrm{L})$. Step-pools evolve towards a condition of maximum flow resistance that implies maximum stability (Abrahams et al., 1995). Flow resistance can be conceived of as the influence of bed roughness on flow velocity. The higher the bed roughness, the less potential energy is available for sediment transport because the mean flow velocity is slowed. Both flume experiments and field measurements show that maximum flow resistance is achieved when the steps are regularly spaced and the mean step steepness $H / L$ (step height/step length) is slightly greater than the channel slope $S$, where $1 \leq H / L / S \leq 2$. This morphology thus represents an equilibrium form adjusted by the flow regime, particle size and slope (Abrahams and Atkinson, 1995; Chin and Wohl, 2005).

This study presents an introduction to the concept of foliaged channel bedforms. Our main objectives are to recognise the fundamental influence of leaves on bedforms, to describe the composition of foliage bedforms, to evaluate various morphometric quantitative parameters and to describe the origin, evolution and function of foliaged bedforms. 
We investigate the following questions:

1. Are there significant differences in basic geometric parameters $(H, L, W)$ between foliaged and unfoliaged step-pool formations?

2. Is there a difference in the grain-size parameters of foliaged step-pools compared to step-pools without leaves?

3. Can the presence of leaves condition the occurrence of step-pool formations?

4. Is the observed increase in step permeability due to the presence of leaves? and

5. How we can determine the stability of foliaged formations? What magnitude of discharge leads to removal of leaves from foliaged steps?

\section{Studied stream}

The Stoligy Stream was used as a reference stream in this study. The stream is located in the eastern part of the Moravskoslezské Beskydy Mts. in the Western Carpathian Flysch Belt (Fig. 2), and it is a left-side tributary of the Lomná Stream. The total length of the studied channel- reach is $160 \mathrm{~m}$ and the channel-reach begins at an altitude of $608 \mathrm{~m}$ a.s.l. The watershed area above the studied reach is $0.26 \mathrm{~km}^{2}$ and the mean channel gradient is $0.14 \mathrm{~m} / \mathrm{m}$. The valley bottom has a gully-like character; the stream is incised into the transport and accumulative zone of a Pleistocene landslide, and active development of the banks has resulted in high delivery of fine claystone sediments from bank failures. The typical channel-reach morphology is step-pool, occasionally alternating with cascades and rapids.

The studied watershed is underlain by flysch rocks of the Godula Member. Alternating layers of resistant sandstone and soft claystone predispose the area to both deep and shallow landslide activity (e.g. Hradecký and Pánek, 2008; Pánek et al., 2011). The grain-size parameters of the bed sediments $\left(d_{50}, d_{90}\right)$ are generally lower in flysch-based streams than in streams in other geological settings. In spite of this fact, very low critical condition values were obtained for bedload transport of certain grain-size fractions in local headwater channels (Galia et al., 2015). In addition, the local streams are prone to accelerated erosional processes when low sediment volumes are available for fluvial transport (Galia and Škarpich, 2013; Škarpich et al., 2013).

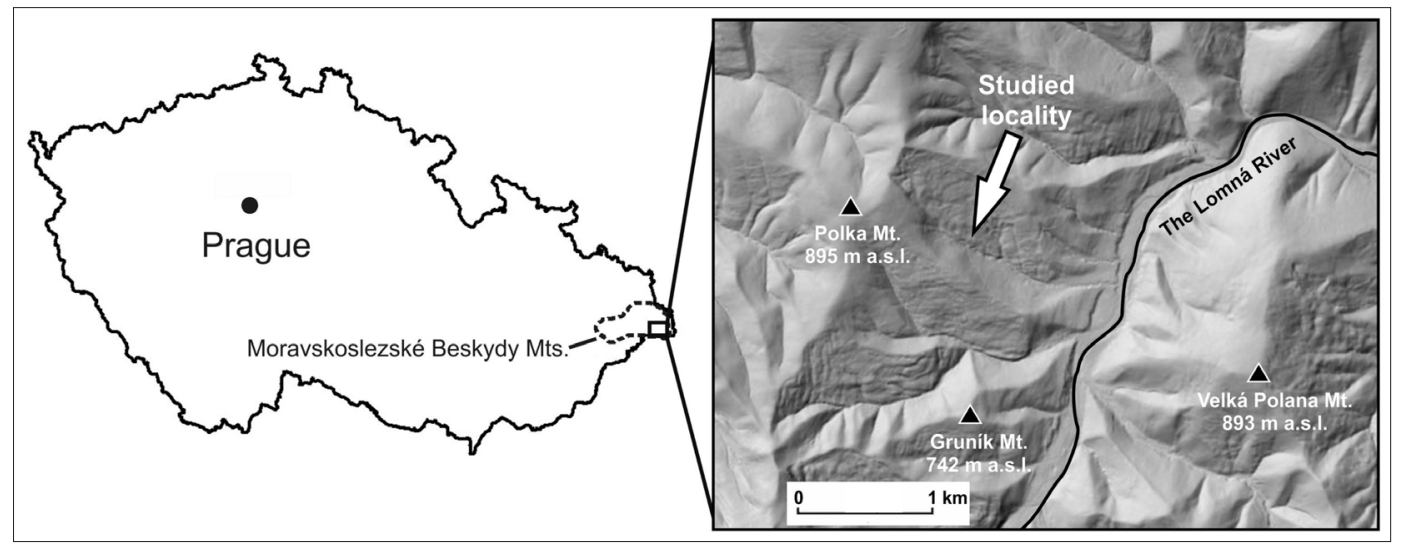

Fig. 2: Location of the studied stream. Source: State Administration of Land and Cadastre; authors' elaboration

The studied watershed is covered by an agricultural forest dominated by beech (Fagus sylvatica), which is the main source of leaf litter in the channels. Maple (Acer pseudoplatanus) also occurs in the study area. The natural character of the gullies and the stepped morphology of the channels form a biotope suitable for a variety of amphibians (e.g. Rana temporaria and Salamandra salamandra) and invertebrate aquatic animals. Small wood pieces were the dominant type of woody material present in the studied channel; thus, we later refer to the steps created by woody material as SW steps. Occurrence of LW in the studied channel was uncommon because of intensive local forest management, which includes removal of logs from the channel.

\section{Methods}

Leaf accumulations (an equivalent is "leaf litter patches", sensu Hoover et al., 2006; Kochi et al., 2009) refer to clusters of leaves that accumulate in channels because of obstacles (e.g. individual boulders, boulder steps or in-stream wood). Leaf accumulations on certain channel units such as steps can be referred to as "leaf formations" (e.g. leaf accumulations on the step). The step-pool formations (SPs) identified in this study were classified into groups based on their origin and rate of foliage $F$ (Fig. 3).

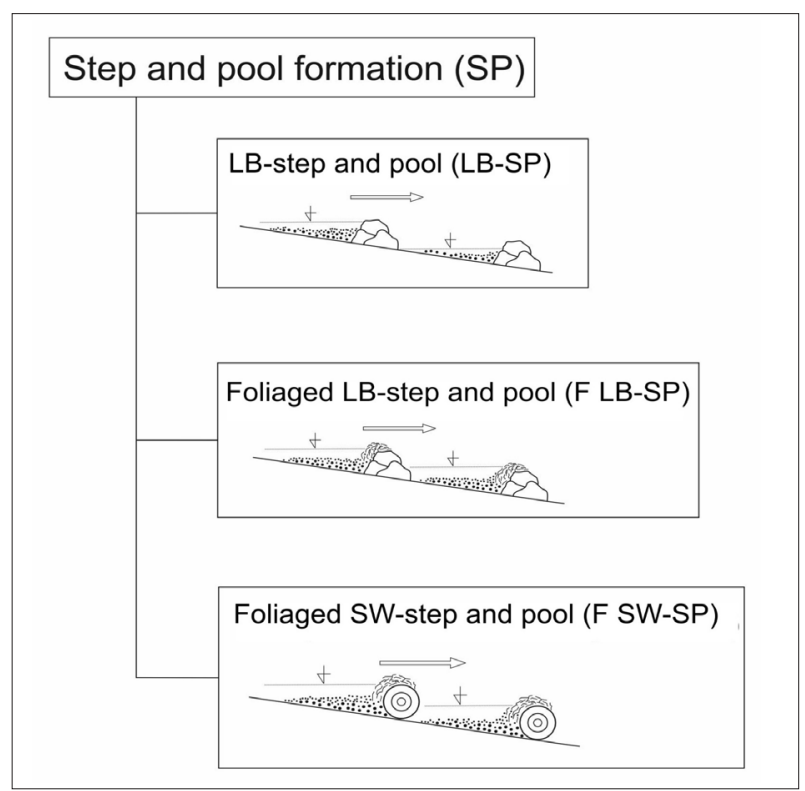

Fig. 3: Types of step-pool formations in the study area. SP is an unfoliaged step-pool formation, F LB-SP is a foliaged large boulder step-pool, and $F \mathrm{SW}-\mathrm{SP}$ is a foliaged small wood step-pool. Source: authors' conceptualisation 


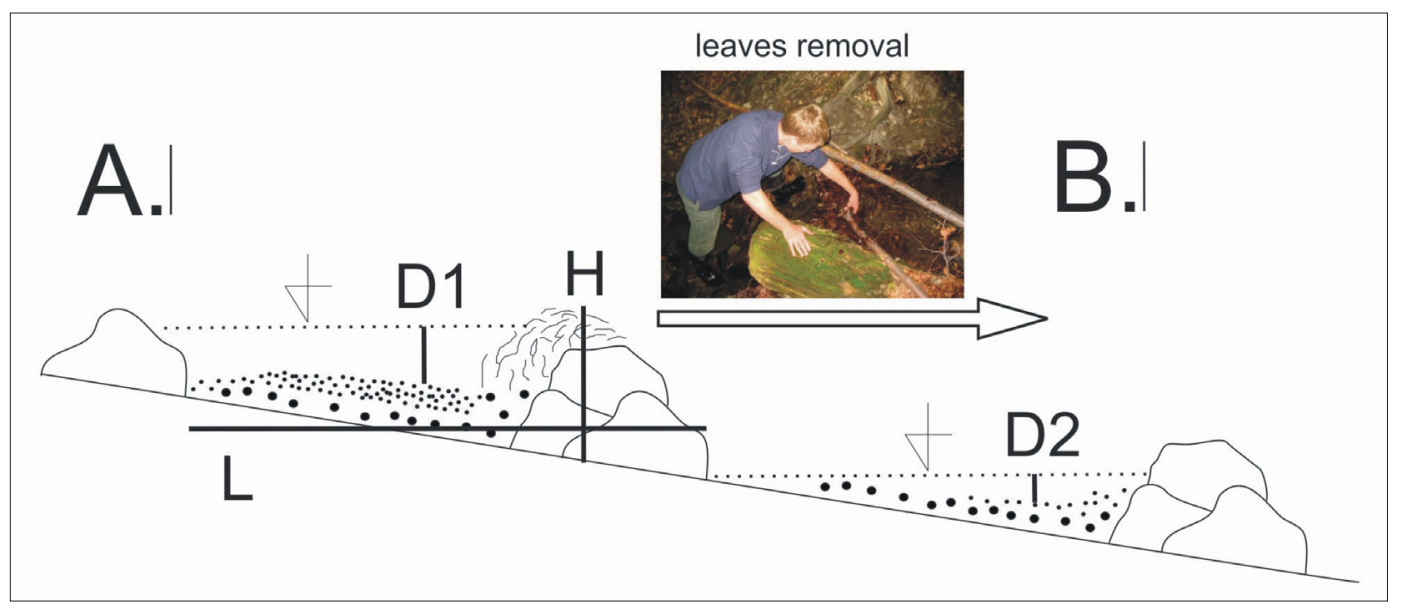

Fig. 4: Measurement of step-pool parameters. A.: measurements of H (height), L (length) and D1 (pool depth); B.: measurements after leaf removal, including D2 (pool depth without leaves). Source: authors' conceptualisation

\begin{tabular}{lccl}
\hline \multicolumn{1}{c}{ Parameter } & Label & Unit & \multicolumn{1}{c}{ Description } \\
\hline Height of step & $H$ & $\mathrm{~m}$ & see Fig. 4 \\
Wavelength (distance between two steps) & $L$ & $\mathrm{~m}$ & see Fig. 4 \\
Pool width & $W$ & $\mathrm{~m}$ & Pool width measured in the first third length of pool \\
Foliage & $F$ & $\%$ & Area covered by leaves on boulder step or SW step \\
Flow concentration & $f C$ & $\%$ & Percentage of scouring water width on a total width of step \\
Depth with leaf & $D 1$ & $\mathrm{~mm}$ & Pool depth measured in the first third length of pool \\
Depth after leaf removal & $D 2$ & $\mathrm{~mm}$ & $\begin{array}{l}\text { Pool depth measured in the same point after removal of leaves on step } \\
\text { Foliage depth }\end{array}$ \\
Relative foliaged depth & $f D$ & $\mathrm{~mm}$ & $\begin{array}{l}D 1-D 2 \\
\end{array}$ \\
\hline
\end{tabular}

Tab. 1: Measured parameters of the step-pool formations. Source: authors' elaboration

The geometry of the step-pools - namely the step height $(H)$, wavelength $(L)$ and channel width $(W)$ - was measured in foliaged and unfoliaged step-pools (Fig. 4). The methodology we used differed from the commonly-used approaches because pools including foliage formations are directly influenced by the characteristics of the downstream steps. In common alluvial SPs, the geometry of pools is usually determined by water drops from upstream steps (e.g. Zimmermann, Church, 2001).

It was necessary to establish a descriptive terminology for foliaged SPs because the literature currently lacks this terminology; this allowed us to define quantifiable parameters that described the sorting and amount of leaves that accumulate in the step-pool systems (Tab. 1). These parameters describe the influence of leaves on the origin and function of the step-pools. Foliage $(F)$ denotes the percentage area of an obstruction (e.g. a boulder step or in-stream wood) covered by accumulated leaves. We used $F$ as a distinguishing factor to determine whether an SP was foliaged or not; an SP was considered foliaged when $F \geq 10 \%$ and leaves were involved with filling the pores between individual boulders or pieces of instream wood. In other words, the presence of leaves could affect the water level in a pool. The flow concentration $(f C)$ indicates the percentage ratio of the concentration of water scour from steps during ordinary flow. Thus, $f C$ represents the ratio between the step width and the concentrated water flow on the crest of a step. This parameter was also affected by the amount of leaves on a step for foliaged SPs (Fig. 5). D1 denotes pool depth in SPs, while $D 2$ is the pool depth after careful removal of leaves

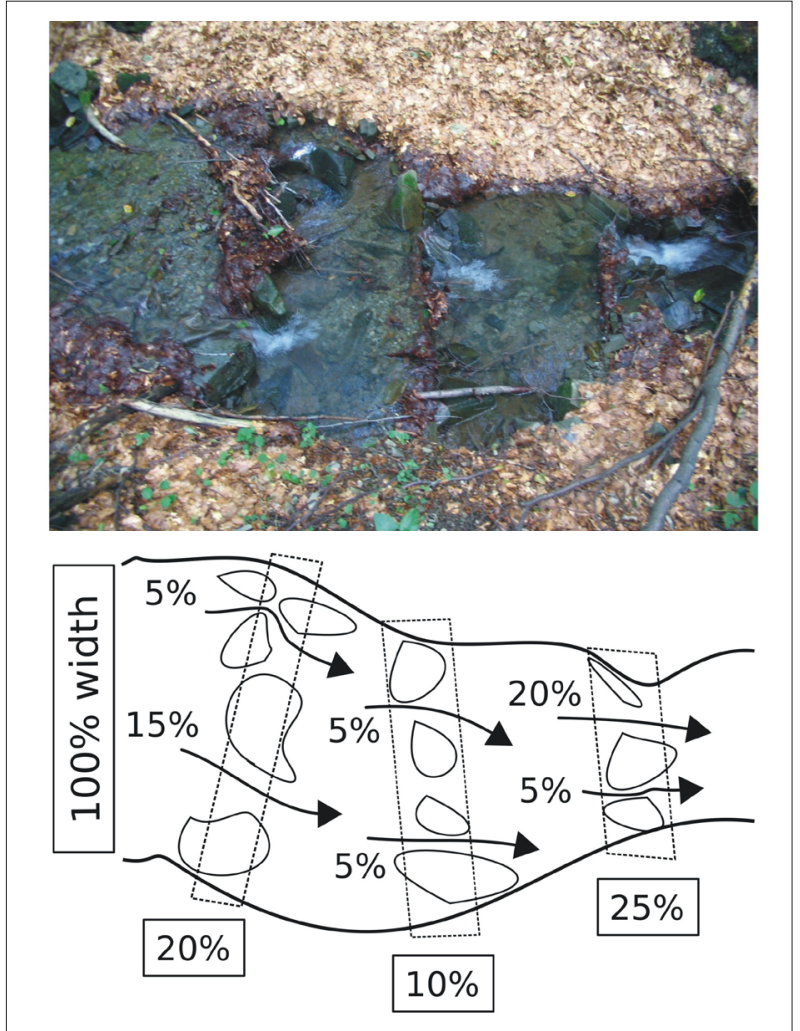

Fig. 5: Description of the parameter flow concentration fC Source: authors' elaboration 
from a step, ensuring that the structure of the step was preserved. Both $D 1$ and $D 2$ were measured at the same point, one third of the pool length halfway through the channel cross-section. The variance in depth $(D 1-D 2)$ is defined as the foliage depth $f D$. This parameter represents the height of water affected by the presence of leaf accumulations on a step; it can be applied when retention of water in the foliaged SPs is considered. Relative foliaged depth $(f D \%)$ denotes the percentage ratio of foliaged pool depth to pool depth after leaf removal: $f D \%=f D / D 1 \times 100$. A correlation matrix was used to find the relationships between all parameters and calculate $p$ statistics.

A standardised measuring template was used to measure the five largest boulders in every step. Fine sediments were taken from pools of foliaged $(n=4)$ and unfoliaged SPs $(n=3)$ in August of 2008. Sieving analysis was performed using a Fritsch sieving aperture and the data were evaluated using Gradistat, a freely available extension of Microsoft Excel.

\section{Results}

\subsection{Geometric parameters of the step-pools}

Table 2 shows the mean values of the evaluated parameters for individual types of SPs. Foliaged SPs have notably larger geometric parameter values $(H, L, W)$ than unfoliaged formations. The correlation matrix between the LB-SP, F LB-SP and F SW-SP variables showed a variety of relationships. Comparing the correlations between individual geometric parameters $(H, L$, and $W)$ showed that the strongest correlation occurred in the LB-SP set. In general, their proportions were strictly related to the channel gradient, discharge and grain-size parameters (Tab. 3). Only the $L$ vs. $W$ linear relationship, however, was statistically significant at $\alpha=0.05$ because of the low number $(n=9)$ of observations. There were lower correlations between geometric parameters for F LB-SPs (Tab. 4), where leaves had an influence on SPs. The F SW-SP formations showed very little correlation (Tab. 5), suggesting that SW and leaf litter led to the formation of SPs and traditional morphogenetic factors (channel gradient, discharge, and particle size) only had a weak influence; the occurrence of SW was the leading factor. The step height increased with size of the largest boulders in the steps for both unfoliaged $(r=0.66)$ and foliaged SPs $(r=0.39)$. Thus, the step height was directly related to size of key boulders in the steps and not to the amount of leaves in the steps.

The depth $D 1$ had a positive correlation $(r=0.47-0.54)$ with the step height $\mathrm{H}$ in all types of observed step-pool formations, probably because pool depth is controlled by water scour from the upstream step in step-pool channels (Lenzi and Comiti, 2003). In addition, D1 correlated strongly with $D 2$ for F LB-SPs and F SW-SPs. Thus, the pool depth is related to various step parameters prior to its foliation. The depth $D 2$ was significantly lower in foliaged formations than the $D 1$ pool depths in unfoliaged SPs, suggesting that leaf litter increased pool retention. Considering the pool geometry, there was a good but not statistically significant correlation between the pool depth $D 1$ or $D 2$ with $W$ for the group of non-foliaged LB-SPs.

Foliation $(F)$ had no correlation with the step height and only a poor correlation with $L$ and $W$. There was a strong negative relationship between foliation ( $r$ was -0.42 for $\mathrm{F}$ LB-SPs and -0.70 for F SW-SPs) and the concentration of flow on the steps $(f C)$. Thus, a decrease in $f C$ was associated with an increase in step foliation. Foliation also correlated with the foliaged depth ( $f D \%)$, showing that increasing step foliation caused an increase in foliaged depth. The observed correlation was stronger for the F SW-SP group than the F LB-SP group and foliation usually reached higher values in the F SW-SP group (76\%) than in the F LB-SP group (57\%). A similar trend was described by Kochi et al. (2009), who found that senescent leaves accumulated in higher volumes on LW steps than on boulder steps (in a ratio of $60: 40$ ). The concentration of flow on the step $(f C)$ indicated that there was a strong negative correlation with step height and

\begin{tabular}{|c|c|c|c|c|c|}
\hline Parameter & All SP & $\begin{array}{l}\text { Unfoliaged SP } \\
\quad \text { (LB-SP) }\end{array}$ & Foliaged SP & $\begin{array}{c}\text { Foliaged large } \\
\text { boulder-SP } \\
\text { (F LB-SP) }\end{array}$ & $\begin{array}{c}\text { Foliaged small } \\
\text { wood-SP } \\
\text { (F SW-SP) }\end{array}$ \\
\hline Number of SP (n) & 59 & 9 & 50 & 29 & 21 \\
\hline$H(\mathrm{~m})$ & 0.29 & 0.22 & 0.30 & 0.31 & 0.28 \\
\hline$L(\mathrm{~m})$ & 1.32 & 1.09 & 1.36 & 1.38 & 1.33 \\
\hline$W(\mathrm{~m})$ & 1.09 & 1.03 & 1.11 & 1.05 & 1.19 \\
\hline$H / L$ & 0.23 & 0.21 & 0.24 & 0.24 & 0.23 \\
\hline$H / L / S$ & 1.66 & 1.52 & 1.71 & 1.71 & 1.64 \\
\hline$L / W$ & 1.24 & 1.07 & 1.28 & 1.33 & 1.18 \\
\hline$D 1(\mathrm{~mm})$ & 99 & 96 & 100 & 101 & 98 \\
\hline$D 2(\mathrm{~mm})$ & - & - & 68 & 77 & 56 \\
\hline$f D(\mathrm{~mm})$ & - & - & 32 & 24 & 42 \\
\hline$f D \%(\%)$ & - & - & 33.4 & 25.7 & 44.1 \\
\hline$F(\%)$ & - & - & 65.1 & 57.1 & 76.2 \\
\hline$f C(\%)$ & 34.4 & 45.6 & 32.4 & 34.5 & 29.5 \\
\hline$d_{50}$ step $(\mathrm{mm})$ & 108 & 123 & 105 & 105 & - \\
\hline$d_{50} \operatorname{pool}(\mathrm{mm})$ & 5.5 & 5.9 & 5.2 & 5.2 & 5.2 \\
\hline
\end{tabular}

Tab. 2: Means of measured parameters of the step-pool formations. For notation please see Table 1

Source: authors' calculations 
pool depth for the LB-SP group. Thus, the concentration of flow is exclusively controlled by the step height and the boulder size. This is in contrast with foliaged forms, where the concentration was dependent on the amount of leaves on the steps.

Generally, these results show that foliaged SW steppool formations had lower correlations with the geometric parameters of the channels; their measured parameters also varied more. The supply of SW to channels is random, so the presence of steps does not reflect local conditions such as the channel gradient, bankfull parameters or grainsize parameters. Foliaged SW step-pools are more likely to be influenced by leaf litter. Unfoliaged LB-SPs and foliaged LB-SPs are more likely to have local parameters that predispose them towards stepped-bed morphology.

\subsection{Retention potential of foliaged step-pool formations}

The parameter that most reflected the influence of leaf litter on channel bedforms was the relative foliaged depth $(f D \%)$. We suggest that the presence of leaves in bedforms, which is expressed by an increase in $f D \%$, has a strong effect on step impermeability, grain size parameters of the pools, flow velocity at the step and in the pool and bedform stability. We observed a rapid decrease in pool depth (D2) and the immediate transport of bed material such as finer sediment, small twigs and accumulated leaves from the pool during leaf removal from the steps.

The mean value of the relative foliaged depth in Stoligy Stream was $33.4 \%(f D=32 \mathrm{~mm})$. A large difference was observed between foliaged large boulder step-pools and foliaged SW step-pools, which respectively had $f D \%$ values of $22.8 \%(f D=23 \mathrm{~mm})$ and $41.8 \%(f D=41 \mathrm{~mm})$. We note that the foliaged depth did not change after removal of leaves in the nine cases of the F LB-SP group. This observation implies that leaf accumulations have a greater influence on the morphometric parameters of woody debris steps than on boulder steps.

\subsection{Evolution of foliaged step-pool formations}

We observed mutual spatial storage of leaves and fine sediments during removal of leaves from foliaged steps. We distinguished two special cases of foliaged steps and pools (Fig. 6). Type $A$ represents the foliaged LB-SP sequence, which generally originated because of the accumulation of leaves on steps (Fig. 6A). In this sequence, an originally rapid channel reach gradually shifted towards a step-

\begin{tabular}{lccccc}
\hline $\mathbf{n}=\mathbf{9}$ & $\boldsymbol{H}$ & $\boldsymbol{L}$ & $\boldsymbol{W}$ & $\boldsymbol{f C}$ & $\boldsymbol{D} \mathbf{1}$ \\
\hline$H$ & $\mathbf{1}$ & & & & \\
$L$ & 0.39 & $\mathbf{1}$ & & & \\
$W$ & 0.60 & $\mathbf{0 . 8 8}$ & $\mathbf{1}$ & & \\
$f C$ & -0.48 & 0.03 & -0.13 & $\mathbf{1}$ & \\
$D 1$ & 0.49 & 0.42 & 0.60 & 0.15 & $\mathbf{1}$ \\
\hline
\end{tabular}

Tab. 3: Correlation matrix for LB SPs with related p-values. Significant correlations at the 0.05 level are denoted in bold letters. For notation please see Table 1 Source: authors' elaboration

\begin{tabular}{|c|c|c|c|c|c|c|c|c|c|}
\hline $\mathrm{n}=\mathbf{2 9}$ & $\boldsymbol{H}$ & $L$ & $W$ & $f C$ & $F$ & $D 1$ & D2 & $f D$ & $f D \%$ \\
\hline$H$ & 1 & & & & & & & & \\
\hline$L$ & 0.44 & 1 & & & & & & & \\
\hline$W$ & 0.35 & 0.57 & 1 & & & & & & \\
\hline$f C$ & 0.09 & -0.43 & -0.10 & 1 & & & & & \\
\hline$F$ & 0.09 & 0.37 & 0.03 & -0.42 & 1 & & & & \\
\hline$D 1$ & 0.47 & 0.17 & 0.26 & --0.05 & -0.16 & 1 & & & \\
\hline$D 2$ & 0.37 & -0.04 & 0.27 & 0.20 & -0.45 & 0.88 & 1 & & \\
\hline$f D$ & 0.13 & 0.41 & -0.07 & -0.51 & 0.64 & 0.09 & -0.39 & 1 & \\
\hline$f D \%$ & 0.12 & 0.29 & -0.15 & -0.39 & 0.71 & -0.22 & -0.62 & 0.88 & 1 \\
\hline
\end{tabular}

Tab. 4: Correlation matrix for foliaged LB SPs with related p-values. Significant correlations at the 0.05 level are denoted in bold letters. For notation please see Table 1. Source: authors' elaboration

\begin{tabular}{|c|c|c|c|c|c|c|c|c|c|}
\hline $\mathrm{n}=\mathbf{2 9}$ & $\boldsymbol{H}$ & $L$ & $W$ & $f C$ & $F$ & $D 1$ & D2 & $f D$ & $f D \%$ \\
\hline$H$ & 1 & & & & & & & & \\
\hline$L$ & 0.33 & 1 & & & & & & & \\
\hline$W$ & -0.17 & 0.22 & 1 & & & & & & \\
\hline$f C$ & 0.13 & -0.11 & -0.24 & 1 & & & & & \\
\hline$F$ & -0.11 & 0.25 & 0.24 & -0.70 & 1 & & & & \\
\hline$D 1$ & 0.54 & -0.09 & -0.19 & 0.15 & -0.06 & 1 & & & \\
\hline$D 2$ & 0.49 & -0.16 & -0.12 & 0.51 & -0.45 & 0.80 & 1 & & \\
\hline$f D$ & 0.13 & 0.09 & -0.12 & -0.53 & 0.58 & 0.41 & -0.23 & 1 & \\
\hline$f D \%$ & 0.16 & 0.32 & -0.10 & -0.46 & 0.68 & -0.12 & -0.60 & 0.71 & 1 \\
\hline
\end{tabular}

Tab. 5: Correlation matrix for foliaged SW SPs with related p-values. Significant correlations at the 0.05 level are denoted in bold letters. Source: authors' elaboration 
pool morphology because of the presence of leaves in the channel. Development of this formation begins when leaves transported by the stream begin to deposit. Later deposition of leaves on large clusters of coarse sediment increases the retention capacity of the cluster. A step is created as the spaces between individual boulders are plugged by leaves. Fine sediments begin to deposit in the pool, partly covering

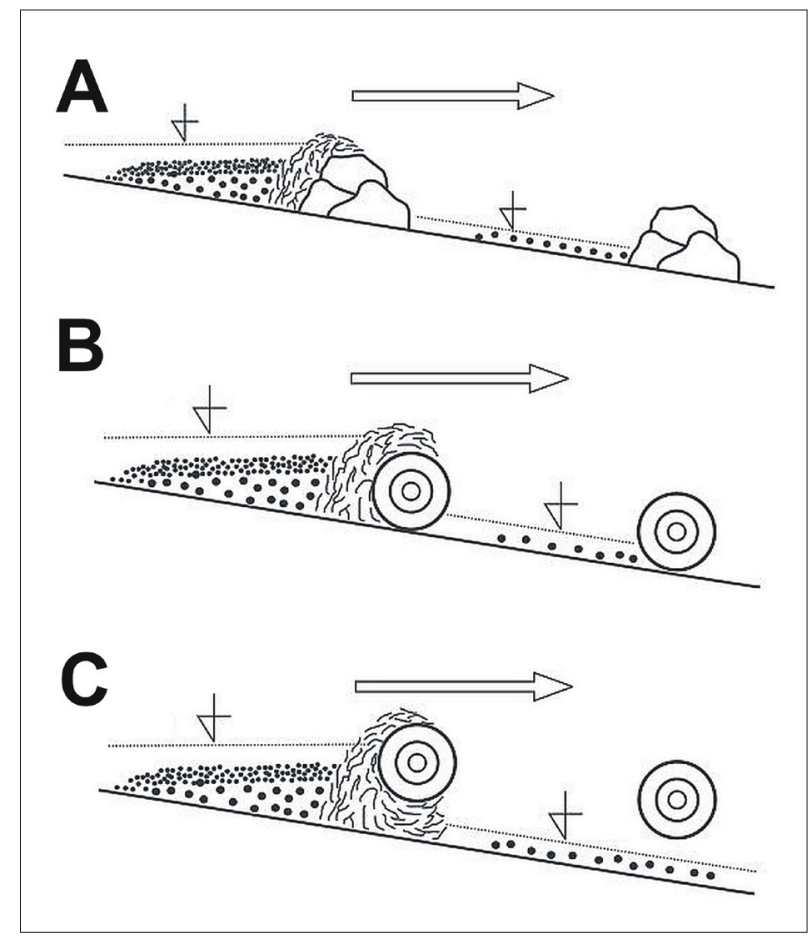

Fig. 6: Different origin of foliaged steps: A - step is created by a group of a few large boulders; $B$ - step is formed by a piece of wood on the channel bottom; and $C$ - step is the result of fallen wood over the channel Source: authors' conceptualisation
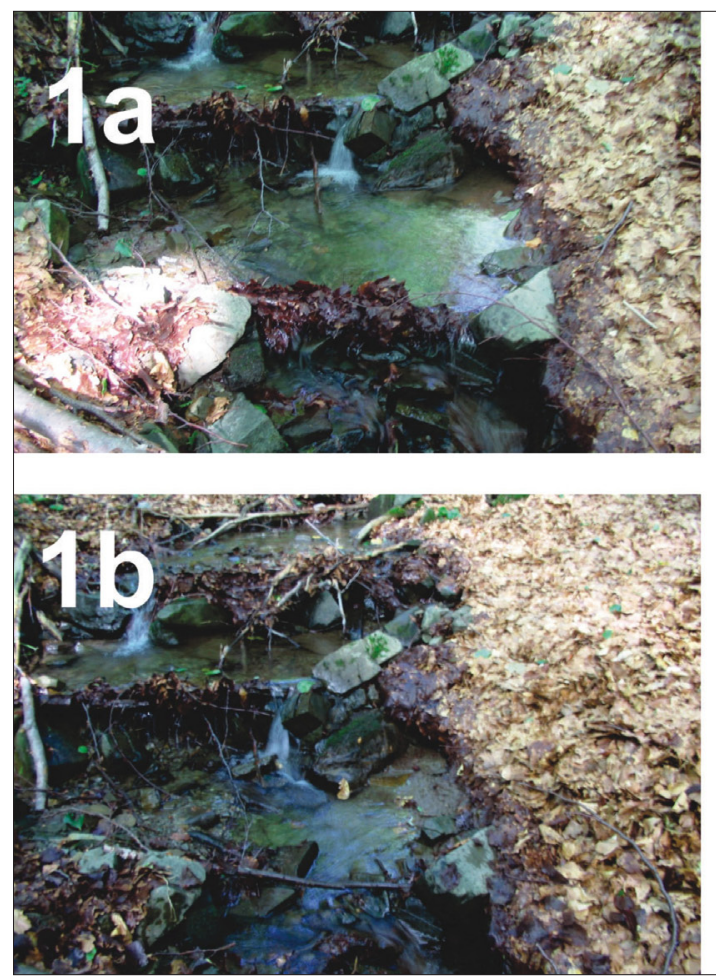

the foliaged step. If leaves are removed from the step, most of the material in the pool is transported downstream, the steppool sequence gradually disappears and the channel-reach morphology is transformed from step-pool back to a rapid nature. Thus, the occurrence of leaves in a channel is the main factor that gives rise to such step-pool morphology. The same situation can arise for SW/LW rather than boulders (Fig. 6B and 6C.) Type $B$ foliaged steps and pools shift from a step-pool to a rapid channel reach morphology after removal of leaves in the case, when the SW/LW is not fully spanning the channel under the level of annual discharge. In contrast, type $C$, which includes the so-called hanging SPs, differs significantly from type $B$ because of the position of logs. In Type $C$, the SW/LW is located above the level of annual discharge, allowing leaves to be transported below this obstruction. A step can only be created when the water level reaches the position of the log during higher discharges. In that case, fine woody debris and leaves fill the space between the channel bed and the log to create a step and pool sequence. Consequently, the pool is then filled by fine sediment, rapid morphology develops after removal of leaves.

We note that removal of leaves caused many step-pool formations to wash out; in total, $60 \%$ of the originally foliaged SW-SPs and $25 \%$ of the LB-SPs were destroyed. These channel reaches were transformed back to rapid reaches or cascades at higher channel gradients (Fig. 7). This result implies that $40 \%$ of all step-pool formations transitioned to this morphology because of the presence of leaves in the active channel.

\section{Discussion}

\subsection{Foliaged step-pool formation geometry}

Our results show that the geometry of foliaged SW-SPs was controlled by the presence of leaf litter. The geometry of the foliaged LB-SP groups reflects other predispositions of stepped-bed morphology (such as the channel gradient
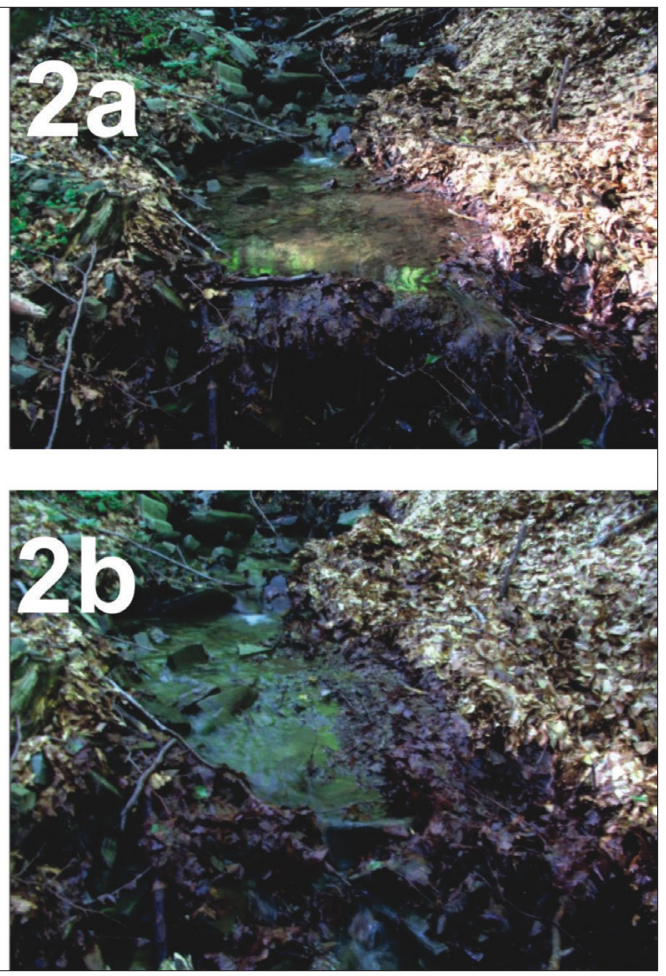

Fig. 7: A change in foliage depth before (a) and after (b) leaf removal, showing significant lowering of the water level. Both figures show steps created by small wood pieces. Source: authors' photographs 
and presence of boulders). There are, however, no previous studies of foliaged stepped-bed morphology that can confirm this conclusion. One exception is the work of Borák (2012) from steep headwater streams. We also compared the geometric characteristics of foliaged step-pools with alluvial (Chin, 1999; Chartrand and Whiting, 2000; Lenzi, 2001; Nickolotsky and Pawlowsky, 2007; Recking et al., 2012; Frandofer and Lehotský, 2013) and bedrock (Duckson and Duckson, 2001) step-pool morphologies that occurred in areas similar to our study location, with small watersheds and steep channel gradients. Borák (2012) investigated foliaged step-pool systems in the flysch-based high-gradient Mazák Stream $\left(A=0.9 \mathrm{~km}^{2}\right)$ in the Western Carpathians, where the mean bankfull width was $1.08 \mathrm{~m}$ and the channel gradient was $0.24 \mathrm{~m} / \mathrm{m}$. He calculated a significantly lower value for the $H / L / S$ relationship (1.05) than we found for the Stoligy step-pools (1.71). The difference is likely due to the steeper channel gradient of the Mazák Stream. The values of other geometric parameters such as the step height and the wavelength were very close to those obtained for the Stoligy Stream (0.33 and $1.31 \mathrm{~m}$ in Mazák and 0.29 and $1.36 \mathrm{~m}$ in Stoligy, respectively). The parameter $L / W$ ranges from 1.07 to 1.33 in the two streams, which shows that the bed pattern for both sites allows a transition between cascades and steppools, sensu Montgomery and Buffington (1997). This implies that foliaged step-pools may be developed in other streams with similar geometric dimensions and conditions in deciduous Western Carpathian forests. Note, however, that Borák (2012) did not examine the occurrence of boulders or SW/LW in Mazák foliaged step-pools.

We observed a smaller step height (less than one half) than was described by Frandofer and Lehotský (2013) in the step-pool channels of the Slovakian Flysch Carpathians $(0.4-0.6 \mathrm{~m})$. The authors also documented a much longer distance between individual steps $(4-6 \mathrm{~m})$ at a mean channel gradient of $0.14 \mathrm{~m} / \mathrm{m}$. The bedrock step-pools investigated by Duckson and Duckson (2001) in very steep bedrock channels $(0.25-0.35 \mathrm{~m} / \mathrm{m})$ composed of volcanic rocks (andesite, basalt and dacite) had similar step heights $(0.2-0.33 \mathrm{~m})$. In contrast, though, the step wavelength and $H / L / S$ ratio measured by these authors was much lower due to their steeper channel gradients. Abrahams and Atkinson (1995) originally reported that the $H / L / S$ ratio falls into the interval $\{1,2\}$ for the adjustment to maximum flow resistance. This is consistent with our findings for foliaged step-pools with both boulders and SW. Significantly higher values with $H / L / S \geq 3$ were found in a large dataset of step-pool reaches in Idaho, USA (Chartrand and Whiting, 2000) and a value of 2.5 was obtained for the steppool channel Cold Creek in California (USA) (Chin, 1999). In both cases, much higher step heights were observed $(0.5-0.6 \mathrm{~m})$. All other step-pool datasets had bankfull parameters and channel gradient values quite similar to the ratios at the Stoligy site, of $0.85<(H / L / S)<1.96$; these include three Californian step-pool streams (Chin, 1999), an Alpine torrent (Lenzi, 2001), step-pools from Arkansas (USA) (Nickolotsky and Pavlowsky, 2007), and step-pool reaches of French Alpine and Vogez headwater channels (Recking et al., 2012). Thus, foliaged step-pool systems are well adjusted to maximum flow resistance, similar to other steep headwaters. Step wavelength seems to be a dependent variable because the individual step heights are strictly influenced by lithological conditions; flysch lithology usually produces relatively finer sediments, creating smaller step heights (Galia and Hradecký, 2014).

\subsection{Aspects of pool retention of the foliaged step-pool formations}

The mean value of the relative foliaged depth in Stoligy was $33.4 \%$. In comparison, Mazák had a relative foliaged depth of 27.3\% (Borák, 2012). These results demonstrate that significantly higher volumes of water are stored in pools because of the presence of leaves in steps. Thus, leaf litter in headwater channels increases water retention in mountain landscapes covered by deciduous forests.

Sediments in pools of step-pool sequences are usually composed of fine gravel and sand (Montgomery and Buffington, 1997). We compared fine pool sediments from both foliaged and unfoliaged step-pool sequences because the presence of leaves in step-pool systems significantly affected pool depth. For Stoligy, we obtained three samples of sediments from unfoliaged pools and four from foliaged pools. We also analysed samples from Mazák, where 13 step-pool sequences were considered to be foliaged and eight were unfoliaged (Borák, 2012). A triangular graph displaying the ratio between gravel, sand and mud grainsize fractions shows obvious clusters of samples (Fig. 8). Samples coming from unfoliaged pools had a higher ratio of the coarsest fraction (in our case, gravel). The opposite situation is true of foliaged pools, which had a higher ratio of sand and mud. The finest fractions are transported past unfoliaged steps during ordinary discharges, whereas leaves in foliaged steps help to trap these fine fractions under the same discharge conditions. This implies that larger volumes of fine sediments are stored in foliaged pools than in unfoliaged ones. Differences in the absolute value of grain sizes between Stoligy and Mazák are most likely related to the different lithology of their sediment supplies, which creates a higher ratio of claystones in the Stoligy Stream; in addition, the two streams have slightly different hydrological conditions and bed material was sampled at different times.

\subsection{Origin and stability of foliaged step-pool formations}

It is important to investigate whether leaves are the principal factor that leads to well-developed step-pool morphology. We assume that foliage of bedforms leads to the formation of step-pool sequences rather than cascade or rapid channel-reach morphology. Foliaged step-pools are a kind of forced channel-reach morphology sensu Montgomery and Buffington (1997). We note that these step-pools have spatial and temporal dynamics. The role of leaves should be considered in the context of their volume in channels because variation in the amount of available leaves would thus determine the characteristics of step-pool morphology, including morphological aspects and stability. Based on the results of Hoover et al. (2006), we suggest that parameters such as the channel gradient, channel width, discharge and size of obstacles in the channels (boulders or SW/LW) are the main factors that influence the foliaged depth or step foliation. The biomorphologic effect of leaves would gradually decrease as discharge and channel width increase and as grain size parameters and channel gradient decrease.

We derived a qualitative model of the evolution and stability of leaf accumulations (Fig. 9), although we note that accurate values of critical conditions (i.e. discharge and flow velocity) for the transport of leaves and fine sediments remain unknown. The model assumes that transport is size-selective; for example, the grain diameter that will move depends on the critical discharge, which was observed in headwater streams in the Flysch Carpathians 


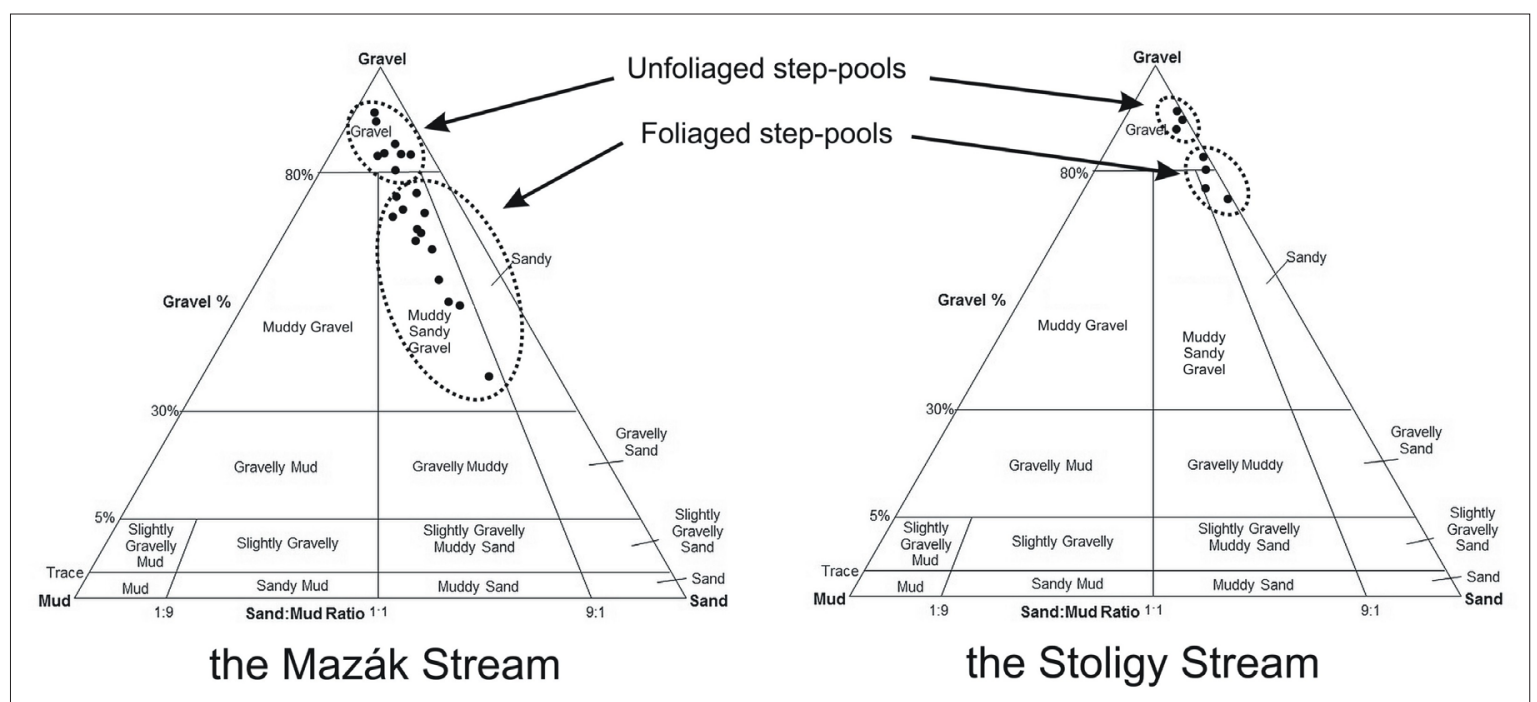

Fig. 8: Grain size characteristics of pools in both foliaged and unfoliaged step-pool formations. Foliaged formations contain finer material than unfoliaged formations. Source: authors' calculations

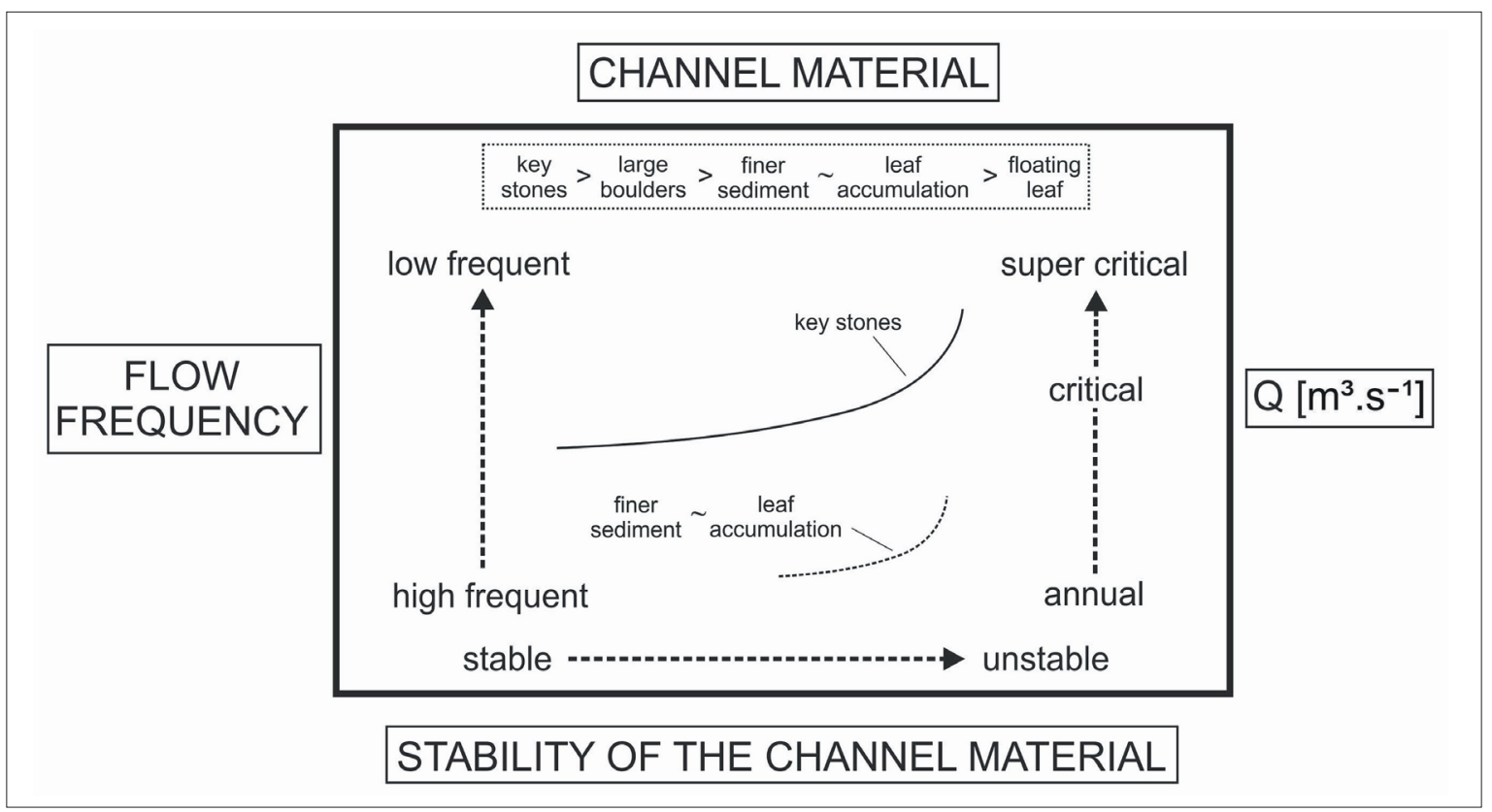

Fig. 9: Qualitative model of channel material transport in streams affected by leaves Source: authors' conceptualisation

(Galia et al., 2015). The size-selective character of bedload transport is typical of well-developed step-pool channels (Montgomery and Buffington, 1997; Chin, 2003). There is evidence that leaves on boulder steps are covered by very fine sediments or that there is a mixture of leaves and fine sediments. This implies that: i) leaves were stored first, followed by storage of fine sediments; or ii) both types of material were accumulated simultaneously. The stability of individual patterns can be expressed in the following form: stable " key stones > large steps boulders (or LW/ $\mathrm{SW})>$ finer pools sediment $\sim$ accumulated leaves $>$ floating leaves » unstable. The model is dependent on the channel width, bed sediment calibre, heterogeneity or occurrence of instream wood, discharge regime and the presence of deciduous trees. Church and Zimmermann (2007) noted that the ratio between the channel width and sediment calibre in steep channels was crucial for development of regular step-pool morphology. For example, Galia and Hradecký (2014) found the ratio $W \leq 20.7 d_{90}$ for step-pool reaches with flysch headwaters and relatively fine bed sediments. Thus, local steep streams in deciduous forests may develop contemporary step-pool reaches on higher $W / d_{90}$ ratios because leaves fill the pores between individual bed grains during the autumn months. These forced step-pools occur until the leaves decay or are washed away during higher discharges (e.g. from snowmelt).

The origin of foliaged step-pool sequences can be described in three basic phases that depend on changes in flow discharge.

1. The first phase occurs during relatively low discharges in originally rapid, step-pool or cascade channels. Leaves are transported through the channel and randomly stored on steps, larger boulders, boulder clusters or pieces of SW/LW. Foliation and plugging of spaces between individual boulders occurs during this phase. The leaves are compressed by the flowing water and begin to create an isolated layer on steps, causing an 
increase in water depth. The increase in step height lowers the flow velocity, leading to the development of pools above the steps. Water begins to flow over the crest of the steps and spaces between individual boulders are fully filled by compressed leaves. The leaves are not orientated randomly; they are mostly stored with the vertical direction of their main axis presented by a scape (Přibyla and Hradecký, 2009; Borák, 2012).

2. Leaves become more compressed during higher discharges in the second phase, when stabilisation of leaf accumulations on steps occurs. Massive isolation layers develop on the steps, connecting individual leaves to each other because of adhesive forces. Once a step is completely foliaged, water scour is concentrated into a narrow space on the step and has a high flow velocity. Fine sediments are stored in the pools and partially in the foliaged layer on the step.

3. The third phase commences when discharge increases; leaves begin to flow out of the steps as the threshold value of leaf stability is exceeded. Destruction of the leaf layer is accompanied by the release of fine sediments from the pools that were formed by the presence of leaves on steps. Removal of the leaves may destroy several step-pool sequences and the channel-reach morphology shifts to a rapid (or cascade) channel. The rest of the step-pool sequence involves a change in the water depth of the pools and a slight coarsening of the bed material in the pools. Leaves can begin accumulating again once discharge decreases and sufficient leaves are available in the channel.

Phases 1-3 are probably repeated many times during the year (Kochi et al., 2009), depending on conditions such as the discharge regime and delivery of leaves into the channels.

\section{Conclusions}

A new geomorphologic phenomenon was observed in forested steep mountain channels, in which leaf litter significantly affects the development of stepped-bed morphology and sediment transport processes. Step-pool sequences were the most common channel forms in the study area; these involved storage and compression of floating leaves into steps. The step-pool sequences were divided into groups of unfoliaged step-pools, boulder foliaged steppools and small wood foliaged step-pools. Statistical analysis showed differences between foliaged and non-foliaged steppool formations. Small wood step-pools accumulated more leaf litter than boulder step-pools. The accumulated leaves formed layers that increased the pool depth and affected the channel's hydrodynamics and transport of fine bed material. Particle-size analyses demonstrated that foliaged step-pool formations had finer sediment in the pools, which indicates that there are differences in sediment transport processes between foliaged and non-foliaged formations. Channel reaches often shifted from step-pool to rapid morphology after removal of leaves from their foliaged steps. This suggested that leaves were the main factor that caused the formation of well-developed step-pool sequences.

It is obvious that leaf litter plays an important role in headwater channels in deciduous forests but this is not well recognised. We conclude that the presence of leaves in the channel of forested watersheds affects water storage by increasing pool retention. Foliaged formations also create critical habitats for various biota, especially aquatic invertebrates that rely upon detritus inputs such as leaves as their main food sources. The presence of leaves in streams and its influence on channel units has great potential for further investigation and implications in forest management.

\section{Acknowledgments}

The authors would like to sincerely thank both anonymous reviewers and the Editor-in-Chief Prof. Bryn GreerWootten for their very constructive comments, which led to a significant improvement in the manuscript. The study was supported by an internal grant from the University of Ostrava (SGS18/PřF/2015-2016).

\section{References:}

ABRAHAMS, A. D., LI, G., ATKINSON, F. J. (1995): Steppool streams: Adjustment to maximum flow resistance. Water Resources Research, 31: 2593-2602.

BILBY, R. E., WARD. J. W. (1989): Changes in characteristics and function of woody debris with increasing size of streams in western Washington. Transactions of the American Fisheries Society 118: 368-378.

BORÁK, L. (2012): Role listového opadu při formování steppool systémů horských toků Moravskoslezských Beskyd na př́kladu vybraných korytových úseků. Diploma thesis. University of Ostrava, Faculty of Science.

BURROWS, R.M., MAGIEROWSKI, R. H., FELLMAN, J. B., BARMUTA, L.A. (2012): Woody debris input and function in old-growth and clear-felled headwater streams. Forest Ecology and Management, 286: 73-80.

CHARTRAND, S. M., WHITING, P. J. (2000): Alluvial architecture in the headwater streams with special emphasis on step-pool topography. Earth Surface Process and Landforms, 25: 583-600.

CHIN, A. (1999): The morphologic structure of step-pools in mountain streams. Geomorphology, 27: 191-204.

CHIN, A. (2002): The periodic nature of step-pool mountain streams. American Journal of Science, 302: 144-167.

CHIN, A. (2003): The geomorphic significance of step-pools in mountain streams. Geomorphology, 55: 125-137.

CHIN, A., WOHL, E. (2005): Toward a theory for step pools in stream channel. Progress in Physical Geography, 29(3): 275-296.

CHURCH, M., ZIMMERMANN, A. (2007): Form and stability of step-pool channels: Research progress. Water Resources Research, 43, W03415.

COMITI, F., ANDREOLI, A., LENZI, M. A. (2005): Morphological effects of local scouring in step-pool streams. Earth Surface Processes and Landforms, 30: 1567-1581.

COMITI, F., MAO, L. (2012): Recent advances on the dynamics of steep channels. In: Church et al. [eds.]: Gravel Bed Rivers: Processes, Tools, Environments (pp. 353-377). Tadoussac, Québec, Canada.

CURRAN, J., WOHL, E. E. (2003): Large woody debris and flow resistance in step-pool channels, Cascade Range, Washington. Geomorphology, 51: 141-157.

DUCKSON, D. W., DUCKSON, L. J. (2001): Channel bed steps and pool shapes along Soda Creek, Three Sisters Wilderness, Oregon. Geomorphology, 38: 267-279. 
FAUSTINI, J. M., JONES, J. A. (2003): Influence of large woody debris on channel morphology and dynamics in steep, boulder-rich mountain streams, western Cascades, Oregon. Geomorphology, 51: 187-205.

FRANDOFER, M., LEHOTSKÝ, M. (2013): Stupňovitá štruktúra dna koryta vodného toku $\mathrm{s}$ výrazným pozdlžnym sklonom (na príklade horného toku rieky Topl'a). Geografický časopis, 65(2): 141-159.

GALIA, T., ŠKARPICH, V. (2013): Coarse bed sediments in a headwater channel as indicators of fluvial and slopechannel coupling: a case study from the Carpathian mountains (Czech republic). Moravian Geographical Reports, 21(3): 2-12.

GALIA, T., HRADECKÝ, J. (2014): Morphological patterns of headwater streams based in flysch bedrock: Examples from the Outer Western Carpathians. Catena, 119: 174-183.

GALIA, T., HRADECKÝ, J., ŠKARPICH, V. (2015): Sediment transport in headwater streams of the Carpathian Flysch belt: its nature and recent effects of human interventions. In: Heininger, P., Cullmann, J. [eds.]: Sediment Matters (pp. 13-26). Springer International Publishing.

GOMI, T., SIDLE, R. C., WOODSMITH, R. D., BRYANT, M. D. (2003): Characterstics of channel steps and reach morphology in headwater streams, southeast Alaska. Geomorphology, 51: 225-242.

HOOVER, T. M., RICHARDSON, J.S., YONEMITSU, N. (2006): Flow-substrate interactions create and mediate leaf litter resource patches in streams. Freshwater Biology, 51: 435-447.

HRADECKÝ, J., PÁNEK, T. (2008): Deep-seated gravitational slope deformations and their influence on consequent mass movements (case studies from the highest part of the Czech Carpathians). Natural Hazards, 45: 235-253.

KOCHI, K., ASAEDA, T., CHIBANA, T., FUJINO, T. (2009): Physical factors affecting the distribution of leaf litter patches in streams: comparison of green and senescent leaves in a step-pool streambed. Hydrobiologia, 628: 191-201.

LENZI, M. A. (2001): Step pool evolution in the Rio Cordon, Nordeastern Italy. Earth Surface Processes and Landforms, 26: 991-1008.

LENZI, M. A., COMITI, F. (2003): Local scouring and morphological adjustments in steep channels with checkdam sequences. Geomorphology, 55: 97-109.

MÁČKA, Z., KREJČÍ, L. (2010): Morphological and sedimentological effects of woody debris in the channel of the Černá Opava. Geologické výzkumy na Moravě a ve Slezsku, 17: 69-75.

MONTGOMERY, D. R., BUFFINGTON, J. M. (1997): Channel-reach morphology in mountain drainage basins. GSA Bulletin, 109(5): 596-611.
NICKOLOTSKY, A., PAVLOWSKY, R. T. (2007): Morphology of step-pools in a wilderness headwater stream: The importance of standardizing geomorphic measurements. Geomorphology, 83: 294-306.

PÁNEK, T., TÁBOŘÍK, P., KLIMEŠ, J., KOMÁRKOVÁ, V., HRADECKÝ, J., ŠŤASTNÝ, M. (2011): Deep-seated gravitational slope deformations in the highest parts of the Czech Flysch Carpathians: Evolutionary model based on kinematic analysis, electrical imaging and trenching. Geomorphology, 129: 92-112.

PRETTY, J. L., DOBSON, M. (2004): Leaf transport and retention in a high-gradient stream. Hydrology and Earth System Sciences, 8: 560-566.

PŘIBYLA, Z., HRADECKÝ, J. (2009): The influence of leaf accumulations on the function of step-pool systems in mountain streams. In: Mentlík, P., Hartvich, F. [eds.]: Book of Abstracts 8 - State of Geomorphological Research in 2009 (pp. 47-48). Czech Association of Geomorphologists, Kašperské Hory, Czech Republic.

RECKING, A., LEDUC, P., LIÉBAULT, F., CHURCH, M. (2012): A field investigation of the influence of sediment supply on step-pool morphology and stability. Geomorphology, 139-140: 53-66.

RICHARDSON, J.S. (1992): Coarse Particulate Detritus Dynamics in Small, Montane Streams Southwestern British Columbia. Canadian Journal of Fisheries and Aquatic Sciences, 49(2): 337-346.

SCOTT, D. N., MONTGOMERY, D. R., WOHL, E. E. (2014): Log step and clast interactions in mountain streams in the Central Cascade Range of Washington state, USA. Geomorphology, 216: 180-186.

ŠKARPICH, V., HRADECKÝ, J., DUŠEK, R. (2013): Complex transformation of the geomorphic regime of channels in the forefield of the Moravskoslezske Beskydy Mts: case study of the Morávka River (Czech Republic). Catena, 111: $25-40$.

WALLACE, J. B., WEBSTER, J.R., EGGERT, S. L., MEYER, J. L. (2000): Small wood dynamics in a headwater stream. Verhandlungen des Internationalen Verein Limnologie, 27: 1361-1365.

WALLACE, J. B., WEBSTER, J. R., EGGERT, S. L., MEYER, J. L., SILER, E. R. (2001): Large woody debris in a headwater stream: Long-term legacies of forest disturbance. International Review of Hydrobiology, 86: 501-513.

WILCOX, A. C., WOHL, E. E. (2006): Flow resistance dynamics in step-pool channels: 1 . Large woody debris and controls on total resistance. Water Resources Research, 42, W05418.

ZIMMERMANN, A., CHURCH, M. (2001): Channel morphology, gradient profiles and bed stresses during flood in a step-pool channel. Geomorphology. 40: 311-327.

\section{Please cite this article as:}

PŘIBYLA, Z., GALIA, T., HRADECKÝ, J. (2016): Biogeomorphological effects of leaf accumulations in stepped-bed channels: Exploratory study, Moravskoslezské Beskydy Mountains, Czech Republic. Moravian Geographical Reports, 24(3): 13-23. Doi: 10.1515/mgr-2016-0013. 